\title{
Pollution Sources Assesment of Turag River, Bangladesh
}

\author{
Md. Liton Rabbani ${ }^{1}$, Sujan Sarker ${ }^{2}$ \\ ${ }^{I}$ (Instructor \& Head of Construction Technology, Tangail Polytechnic Institute, Bangladesh) \\ ${ }_{2}^{2}$ (Student, B.Sc in Civil Engineering, European University of Bangladesh, Bangladesh)
}

\begin{abstract}
A study was carried out on Turag River with a view to observe and identify the present pollution sources of Turag river. Point and non-point sources of pollution of Turag River have been identified by several times of field visit during the the dry and wet periods of 2014 and 2015. From the field visits, it is clear that there are numerous illegal domestic sewage outfalls directly discharging waste into the river. In the Turag River many types of waste basically semisolid and liquid particles are being discharged every day. The water of the river is polluted mainly by industries, household waste through drainage, hospitals, shops, shopping malls, bazaar, storm water, mobiles or oils from many types of boats, launches etc. In order to decrease pollution from various sources appropriate steps can be taken to reduce the concentration of water quality parameter. Adoption of adequate measures to reduce the level of pollutants from the industrial wastewater and renovation of sewage treatment plants are suggested to avoid further deterioration of the river water quality. It is recommended to implement existing law and regulations, to remove illegal residential and industry building from the bank of river, to establish effluent treatment plant (ETP) etc. To ensure better accuracy, follow up study should be continued also to check the validity and consistency of the results.
\end{abstract}

Keywords: Effluent treatment plant, Industrial Wastewater, Non- Points Sources, Points Source, Turag River.

\section{Introduction}

Bangladesh is considered as a land of rivers. Rivers are said to be the lifeline of this country. The daily livelihoods of millions of people in Bangladesh in terms of transportation, agricultural and fishing practices are directly dependent on the healthy existence of rivers. Moreover, rivers are treated as major sources of drinking water and an inseparable part of the ecosystem. Dhaka city, the capital of Bangladesh, is surrounded by the rivers - Turag, Buriganga, Dhaleshwari, Balu and Shitalakhya. A number of canals are connected to these rivers, which form a river canal network system. River Pollution is one of the main talk about topics among the environmental issues of urban Dhaka [1]. From the beginning of Bangladesh, due to rapid and unplanned urbanization and industrialization precisely in Dhaka, the rivers in the capital including the Turag have been experiencing a number of complicated problems including pollution. Pollution has almost suffocated the valuable lifelines of the city [2]. The river Turag running by the side of the Dhaka city, the capital of Bangladesh, is one of the most polluted rivers in Bangladesh [3]. Many industries have set up in and around the Dhaka city during the last decade, and the number of the new industries is continually increasing [4]. Industry is a small user of water in terms of quantity, but has a significant impact on the quality of water [5]. The major sources that cause pollution to Turag river water are various consumer goods industries (soap and detergent), garments industries, pharmaceuticals industries, lots of tanneries, dyeing industries, aluminum industries, battery manufacturing, match industries, ink manufacturing industries, textile, paint, iron industries, pulp and paper factories, chemical factories, frozen food factories and steel workshop etc. Most of the industries discharge their effluents directly or indirectly into the Turag River without any treatment causing pollution of the surface water. As a result, water used for human consumption, industrial purposes, land irrigation and fish production, is thought to be greatly contaminated by these toxic substances [6]. Moreover, both municipal and industrial solid wastes are also dumped on the bank of the Turag River considering it as an open space which emits noxious smell. During monsoon, solid waste flows through the river and totally disrupts the water quality of the river. The poisonous water of these river has not only been killing all its aquatic life but also been posing health hazards to the dwellers of the city [7]. In this regard, the harmful effects of industrial effluents and solid waste on the quality of water need to be checked to ensure water quality, public health and their well-being [8].

\subsection{History of Turag}

\section{Literature Review}

The Turag River is the upper tributary of the Buriganga, a major river in Bangladesh. The Turag originates from the Bangshi River, the latter an important tributary of the Dhaleshwari River, flows through Gazipur and joins the Buriganga at Mirpur in Dhaka District [9]. It is navigable by boat all year round. Exemplifying the river character of Dhaka, the Turag is abundant in fish but suffers from acute water pollution. While attempts have been made to marginally widen the river, the majority of industry has made little effort to 
follow environmental law and the water has become visibly discolored. Earlier this river was called as (Bengali: "Kohor Doriya"), "Kohor river". Figure 1 shows the peripheral rivers of Dhaka City.

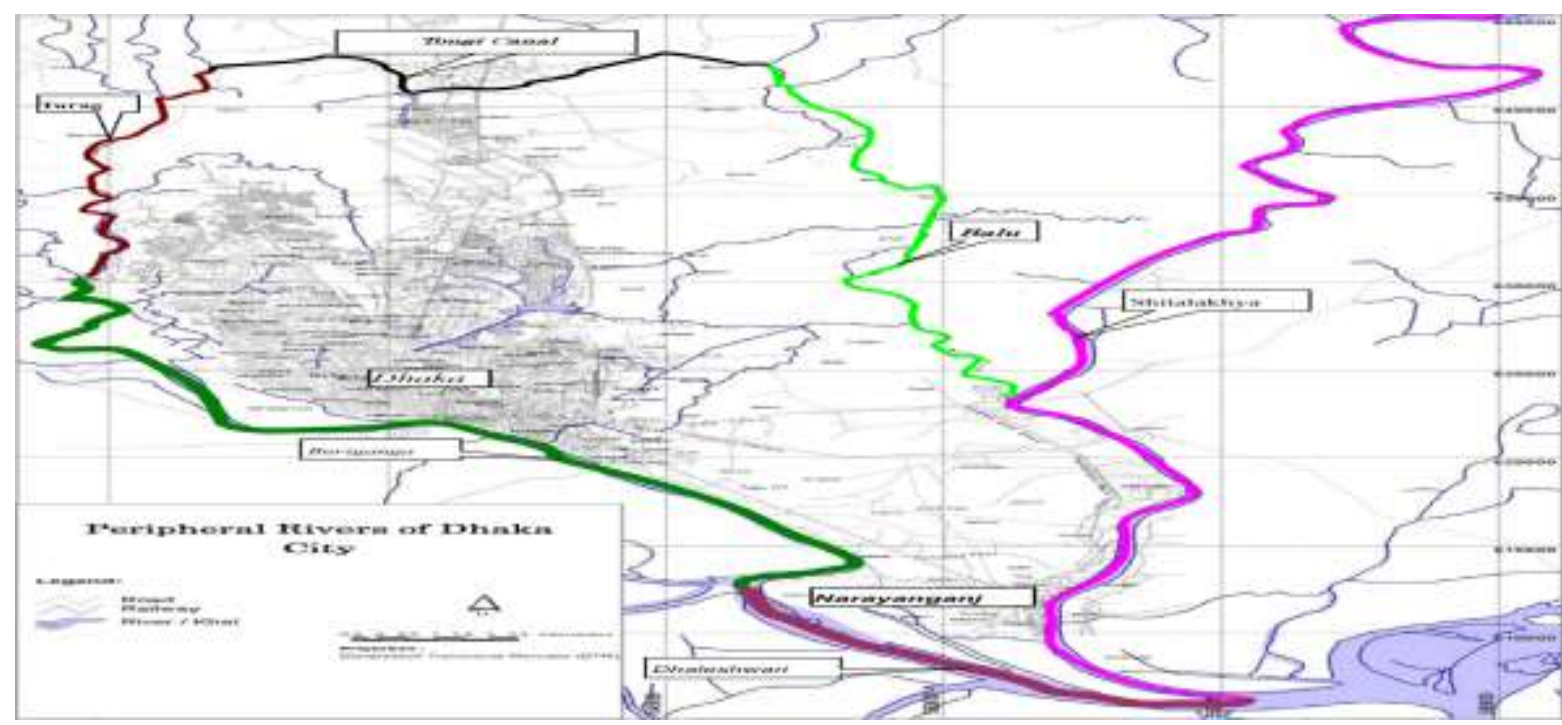

Figure-1: Map of Peripheral Rivers of Dhaka City [15]

\subsection{Pullution Sources Assesment of Turag River}

Pollution can happen in many ways in a river like Turag such as chemically, physically and also biologically. Impairment occurs when the rate at which pollutant materials enter water bodies exceed their natural capacity to assimilate them. Inventories of outfalls discharging into a water body are needed for identification of point sources. Sources are broadly categorized as either "point sources" or "point sources". Point sources are industrial effluent, municipal waste etc. and non-point sources are agricultural runoff and others. Industrial effluents are textile, tannery, dyeing and others [10]. From the above discussion pollution sources can be classified according to figure 2 .

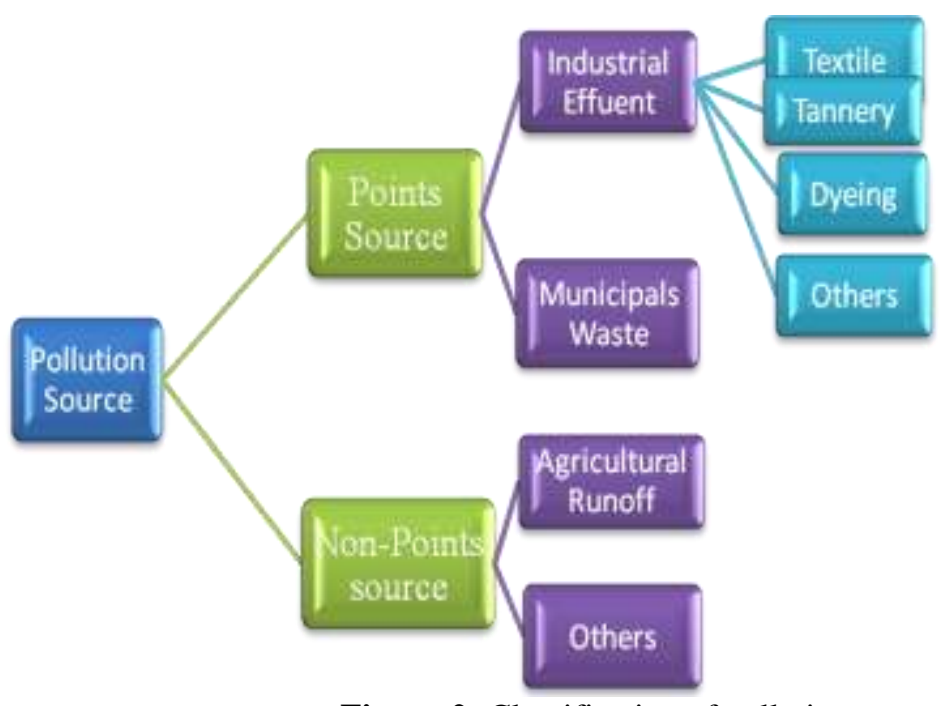

Figure-2: Classification of pollution sources

\subsection{Points Sources}

Point source pollution, on the most basic level, is water pollution that comes from a single, discrete place, typically a pipe. The U.S Clean Water Act [11] specifically defines a "point source" in section 502(14) of the Act. That definition states:

The term "point source" means any discernible, confined and discrete conveyance, including but not limited to any pipe, ditch, channel, tunnel, conduit, well, discrete fissure, container, rolling stock, concentrated animal feeding operation, or vessel or other floating craft, from which pollutants are or may be discharged. This term does not include agricultural storm water discharges and return flows from irrigated agriculture. The U.S. Environmental Protection Agency (EPA) [12] defines point source pollution as "any single identifiable source 
of pollution from which pollutants are discharged, such as a pipe, ditch, ship or factory smokestack". Factories and sewage treatment plants are two common types of point sources. Storm water discharges from separate storm sewer systems of cities and those associated with industry and construction are considered point sources of pollution. Point source pollution consists of waste products discharged from a specific point such as a sewage treatment plant or an industrial facility. The pollutants from these sources can usually be measured and traced to a pipe or a specific "point" of origin. In the Turag River, there are two principle types of point sources. These are:

a) Municipal point sources

b) Industrial discharges

\subsection{Non- Point Sources}

Nonpoint source pollution generally results from land runoff, precipitation, atmospheric deposition, drainage, seepage or hydrologic modification. The term "nonpoint source" is defined to mean any source of water pollution that does not meet the legal definition of "point source" in section 502(13) of the Clean Water Act. Non-point sources include agricultural, sericulture, atmospheric, urban and sub-urban runoff, ground water, drainage from abandoned mines and construction activities, leaching from land disposal and solid waste. Nonpoint source pollution does not have one specific source, such as a factory [14]. Non-point source pollution comes from the cumulative effect of a region's residents going about their everyday activities, such as fertilizing an agricultural land. It results when small amounts of contaminants from a large number of sources are carried by rainfall runoff from construction areas, farms, highways, agricultural activities, septic system discharge, eroding shorelines and washed off lawns and parking lots. Non-point source pollution is difficult to control because it enters the river from a wide geographic areas rather than a specific pipe or point of origin, resulting from the everyday activities of many different people. States report that nonpoint source pollution is the leading remaining cause of water quality problems. The effects of nonpoint source pollutants on specific waters vary and may not always be fully assessed. However, we know that these pollutants have harmful effects on drinking water supplies, recreation, fisheries and wildlife.

\subsection{Identification of Pollution Sources}

\section{Methodology}

Steps of pollutant sources identification are given bellow:

(1) Reconnaissance boat trips were made along the river Turag in November and December, 2014 and several times during 2015.

(2) These trips enabled identification of major pollution sources of Turag River.

(3) Photograph of the sources were taken and analyzed.

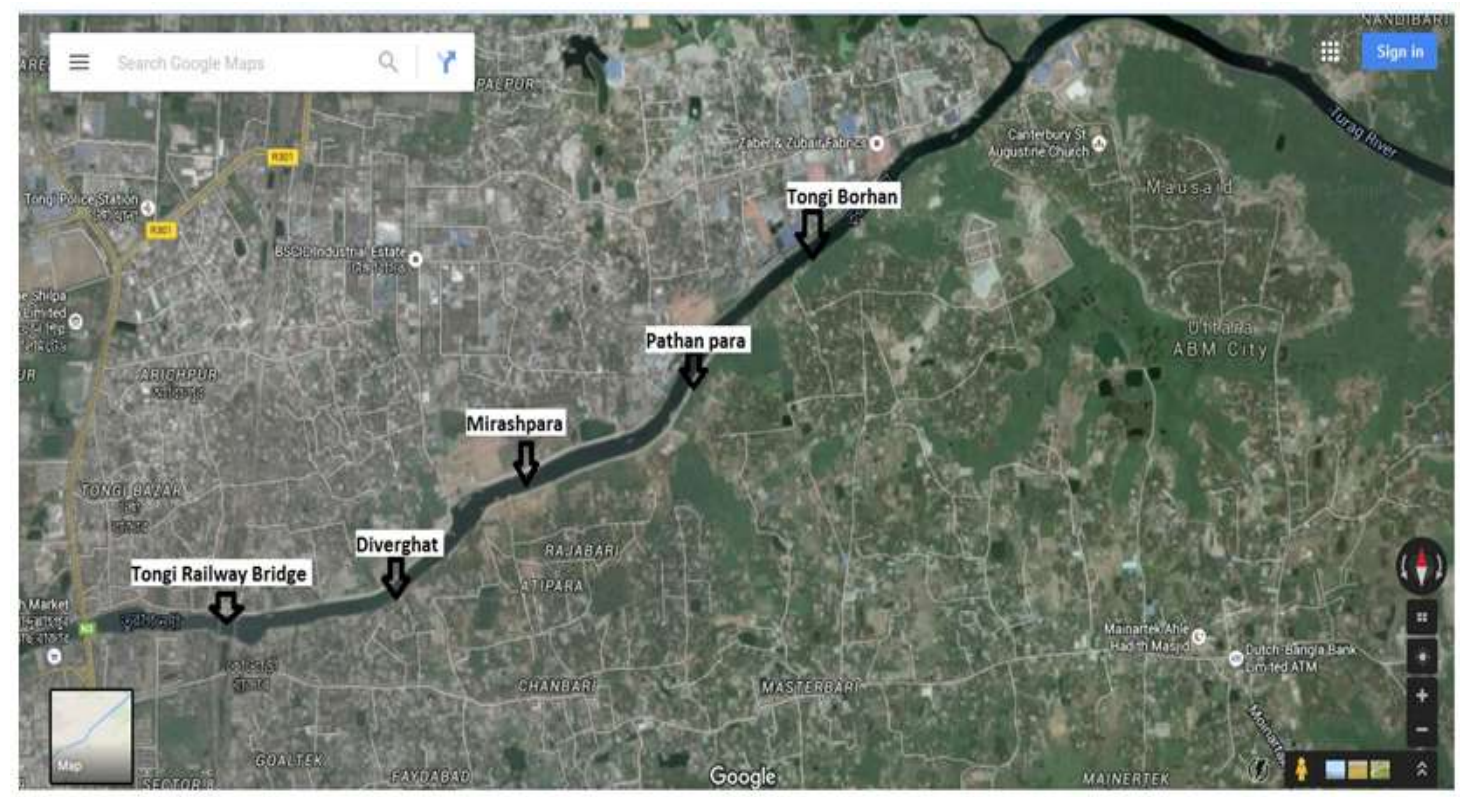

Figure-3: Google View of Study area of Turag River 


\section{Result And Discussion \\ 4.1 Categorization of Pollutant Sources: Point Sources and Non-Points Sources \\ 4.1.1 Point sources pollution for Turag River}

There are very common to observe small/ big establishments like hospitals, clinics, industries, factories etc. with permanent \& temporary (slum/ squatters) building structures areas on the bank of the Turag River. So, identification of point sources of these establishments is very essential but it is a massive work because of their numerous outfalls. The main reason behind this spatial pollution pattern in the Turag within above mentioned area is that huge load of untreated toxic liquid chemical waste is directly dumped into the river from Hazaribagh tanneries through the Bashila Khal at the downstream and from the Tongi Industrial Area at Tongi Bridge and Iztema Field area. This very high pollution concentration literally diffuses to other parts of the river through upstream flow during the rainy season and some tidal activity during the dry season [15]. Through lateral diffusion process, the pollution concentration decreases with increase in distance from the pollution source. Pollution concentration comparatively increases in the dry season when water level of the river recedes a lot. A figure of Solid Waste Dumping along the embankment of Turag River is given in figure 4.

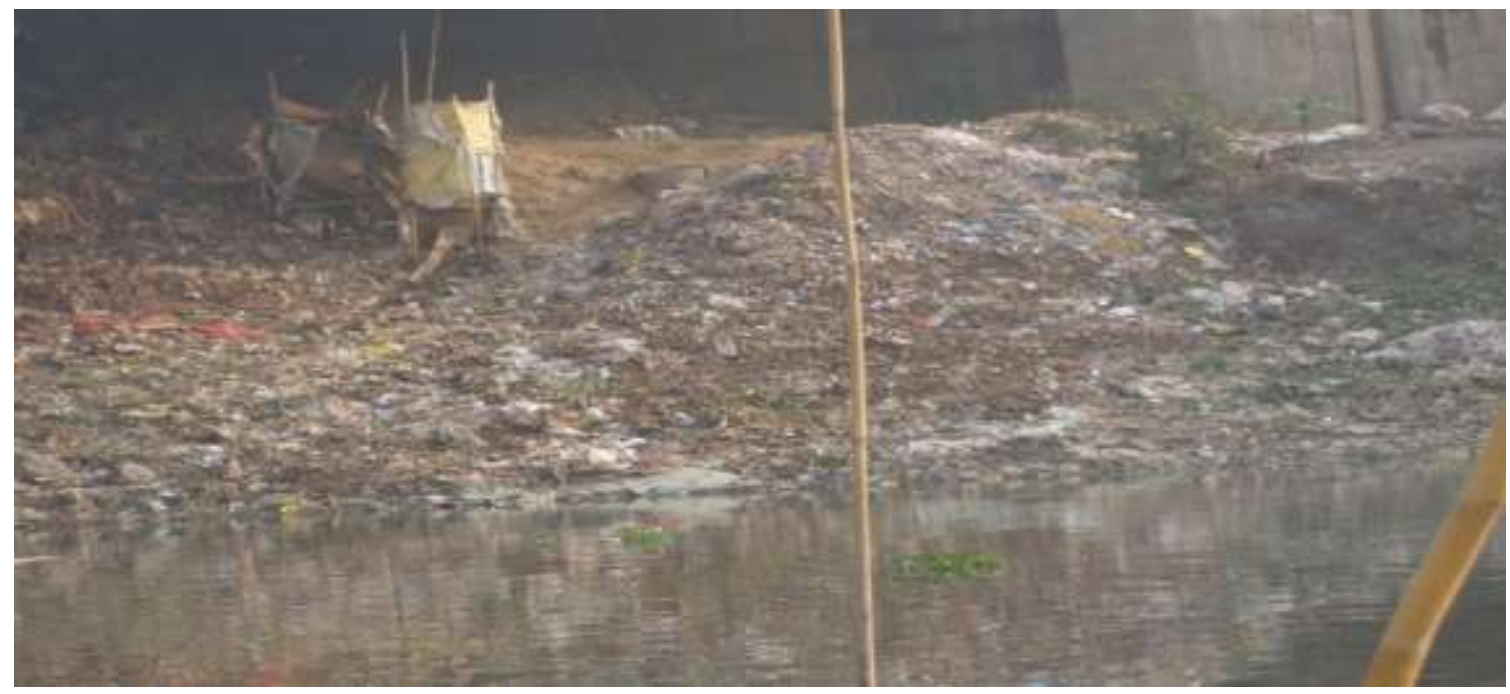

Figure-4: Solid Waste Dumping along the embankment of Turag River

There have been found, according to the field survey, about 28 minor waste disposal outlets to the Turag River. Of them, about 20 are solid (household, commercial, and industrial) waste dumping sites along the embankment which emit huge amount of waste (both bio-degradable and non-bio-degradable) into the river. Along the south- eastern bank of the river, there have been found four sluice gates which dispose huge load of sewerage waste of the DCC area into the river. A figure of Solid Waste Dumping in the Turag River water is given in figure 5.

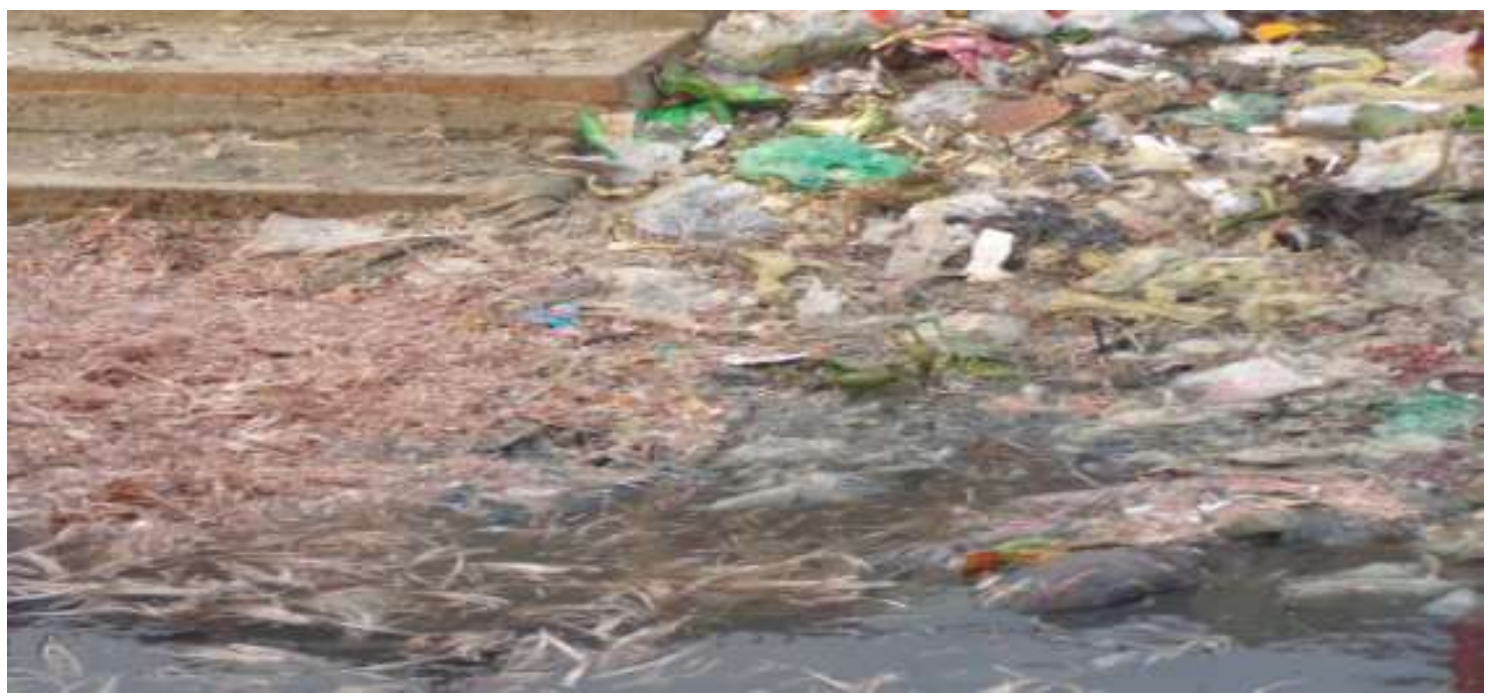

Figure-5: Solid Waste Dumping in the Turag River water 
These points are very important for not only to assess the water quality but also its economical importance. Tongi Industrial basically industrial areas having tannery, soap factories, dying factories etc. These industrial waste water falls directly into river through pipe, canals, open drains etc. and pollute river water very easily. Some solid waste like paper, polybags and bottles fall (Figure 6) and spoil the river water.

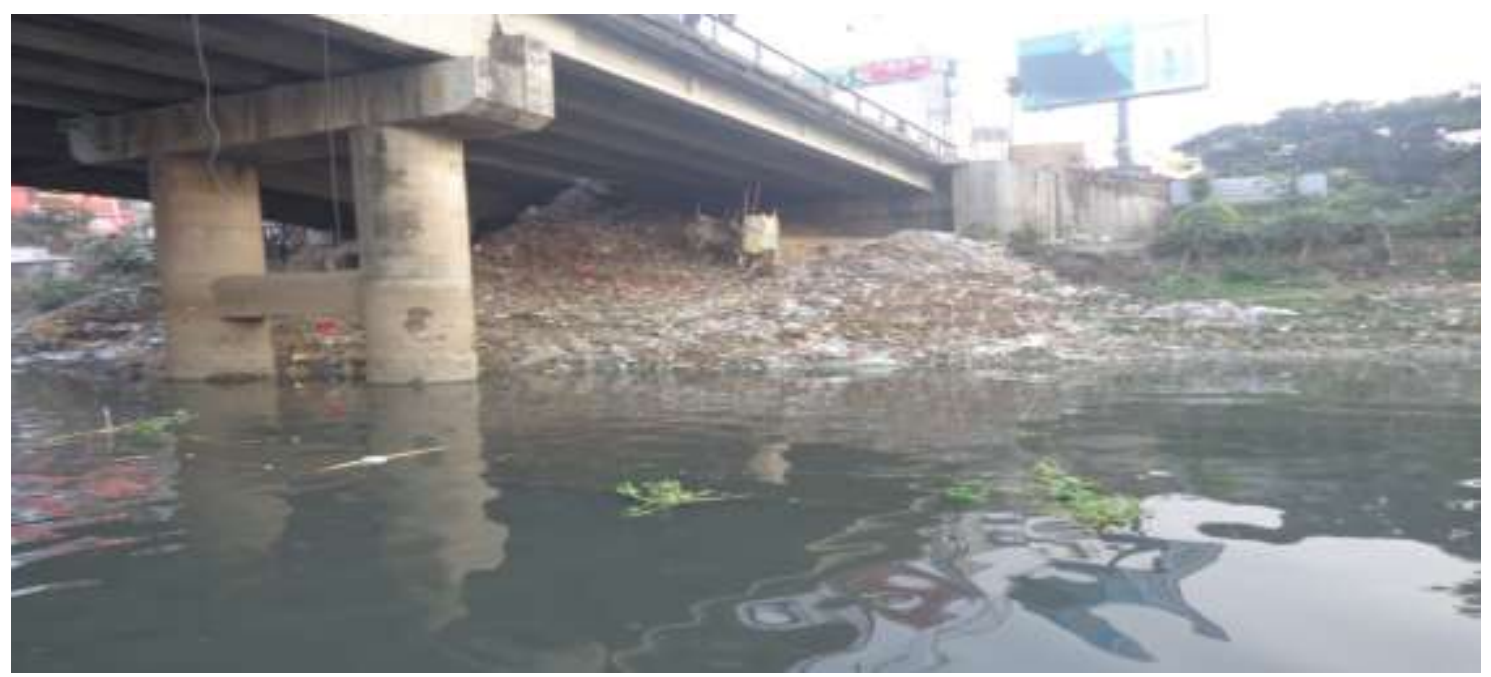

Figure-6: Solid Waste Dumping under the Tongi Bridge of Turag River

Heavy metals like lead, arsenic, zinc etc. easily mixed with water bodies because of lack of ETP (Effluent Treatment Plant) and also inadequate capacity of ETP. According to Bangladesh environmental conservation Rules, it is mandatory to have an ETP for industries but it is not observed for the weakness of law enforcement. Dying factories discharge bleach and hot water without any treatment into the river which is harmful for fisheries.

It observed in some points people connect their sewage lines to the domestic drain illegally and this black water (sewage water) directly discharges into the river (Figure 7) without any kind of treatment. Many slums on the study areas do not have well sanitary management as well as drainage facilities. For this reason, the sewage water directly falls into the river and spoils water quality. Many hospitals and clinics waste line connects with the household drainage line or directly into the river and pollutes the river water quality.

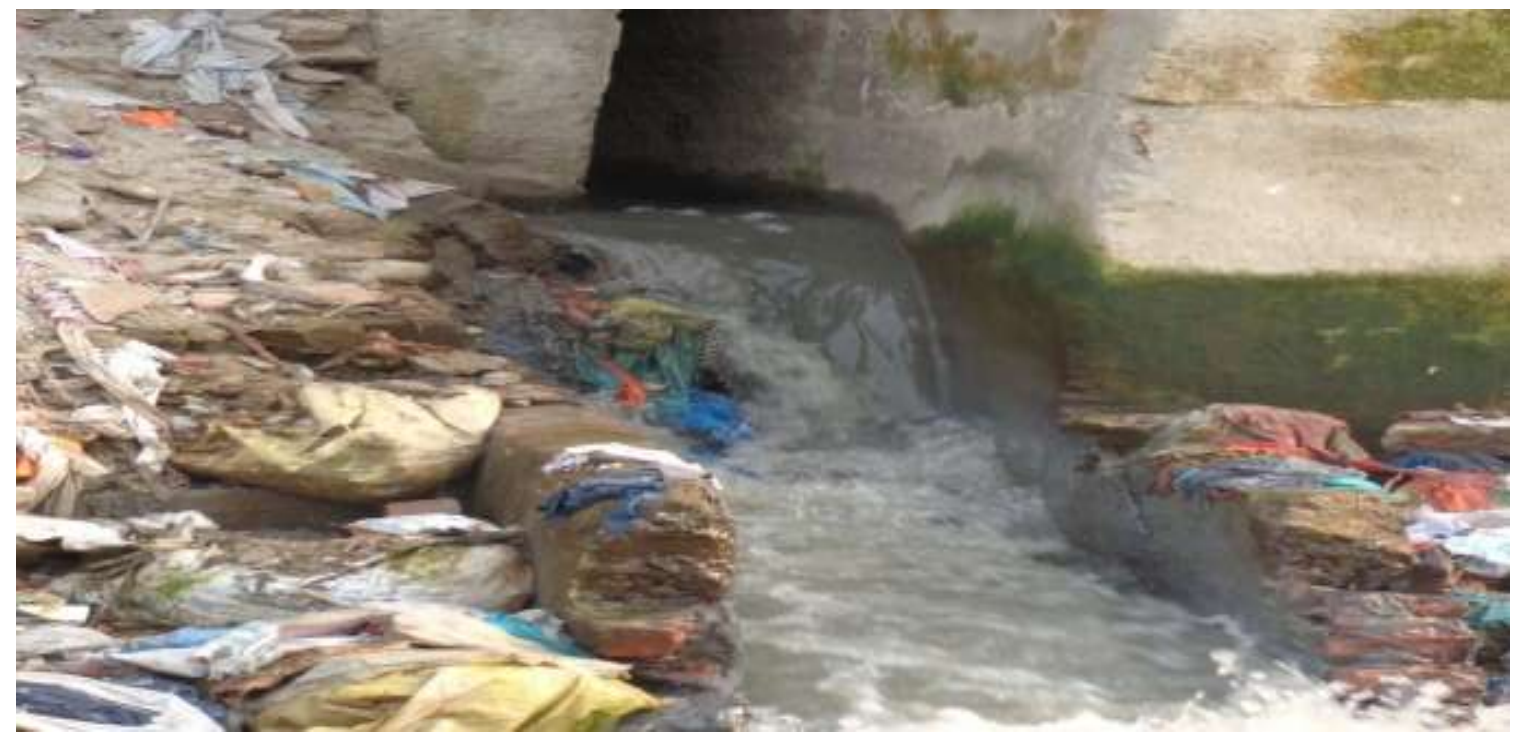

Figure-7: House hold and industrial waste line connection of Turag River

So, general people called the Turag River as one of the drains of the Dhaka city and in some sort of cases it is quite applicable for its blackish color, unbearable odor and of course no aquatic lives in the water. 


\subsubsection{Non -Point Sources Pollution for Turag River}

The river has also a vast non-point source of pollution. Along its north-western bank, there is a vast agricultural land particularly paddy field from Bagchotra, Savar to Tongi Pourosava area. The residue of the chemical fertilizers used in the cultivable land is also added to the pollution of the river through overland flow resulting from heavy downpour during the rainy season. Non-point source for Turag River is mainly because of three mechanisms: storm water runoff, atmospheric deposition and groundwater discharge. Storm water runoff consist of excess rainwater which is not absorbed by the soil or existing vegetation, carries mainly pathogens, nutrients, sediments and toxic substances from land ultimately discharges into river or other water bodies. Runoff occurs in both rural and urban areas. Urban areas like Dhaka where most of the areas are covered with impermeable layers like asphalt, concrete and buildings prevent rainwater from soaking into the ground. So the storm water fall directly into the river and on its way it takes lot of pollutants and also sediments. The Turag River receives discharges from many storm sewer outfalls from the study areas. Unfortunately, the storm sewers usually carry domestic sewage during the dry season and combined flows of domestic sewage and storm water during the wet season. Although many storm sewer outfalls discharge into Turag River at specific points, mainly through pipes, these cannot be strictly treated as "point sources" since the origin of water/wastewater entering into these sewers cannot be ascertained. On the other hand, an illegal domestic and industrial connection to storm sewers is common in the surrounding Dhaka. Hence, the storm sewer outfalls in Turag River could be treated as "non-point source" pollution. So, runoff from surrounding agriculture lands which basically source of fertilizer and agricultural chemicals such as insecticides and herbicides contribute pollution into the River. Atmospheric deposition is most likely to contribute additional amount of nonpoint source pollution to Turag River. As rain forms, it absorbs pollutants from the atmosphere. When it rains, the precipitation that falls within the river can contain small amounts of pollutants. However, considering the gross pollution of Turag River from domestic sewage and other sources, contribution from atmospheric deposition is likely to be insignificant. Ground water contributes also non-point source pollution to the Turag River. Discharges from septic systems, any garbage deposits, hazardous sites etc. may seep into groundwater which then slowly flows into the River. But still non-point source pollution from groundwater discharges is not likely to be significant for Turag River.

\subsubsection{Types of Outfalls}

An outfall is the discharge point of a waste stream into a body of water; alternatively it may be the outlet of a river, drain or a sewer where it discharges into the sea, a lake or the like. In the United States, industrial facilities that discharge storm water which was exposed to industrial activities at the site are required to have a multi-sector general permit. Issuing permits for storm water is delegated to the individual states that are authorized by the EPA. Facilities that apply for a permit must specify the number of outfalls at the site. According to the EPA's 2008 MSGP (final version), outfalls are locations where the storm water exits the facility, including pipes, ditches, swales, and other structures that transport storm water. If there is more than one outfall present, measure at the primary outfall (i.e., the outfall with the largest volume of storm water discharge associated with industrial activity).

As a part of the present study, surveys were carried out for observing the types of outfalls discharging into Turag River during the period of sampling form the study areas. In these areas Turag River receives water/ wastewater from storm sewers (in the form of pipes, channels), which usually carry storm runoff /wastewater/sewerage from domestic/commercial (including hospitals and clinics)/industrial sources. Besides, wastewaters are also discharged into the River directly through a large number of small/ big private (industries, hospitals, commercial, domestic establishments) outfalls (i.e. small/ big diameter pipes, small channels etc).

For Turag River, the major types of outfalls of the study areas discharging into the River have been classified as: (i) Storm sewer pipes (ii) Open channels and (iii) Small / big private outfalls.

\subsubsection{Storm Sewer Pipe Outfalls}

Pipe outfalls are the most easily identifiable outfalls in Turag River. These outfalls are primarily storm sewers discharging into the Turag River. But illegal connections are made from domestic, commercial and industrial establishments into storm sewer. These storm sewers are mostly made of concrete, plastic and metal pipes were also seen. There is often a rip-rap or concrete spillway at the outfall to minimize the potential erosion at the end of the pipe. Figure 8 shows two such storm sewers outfalls, discharging domestic sewage in the wet season. 


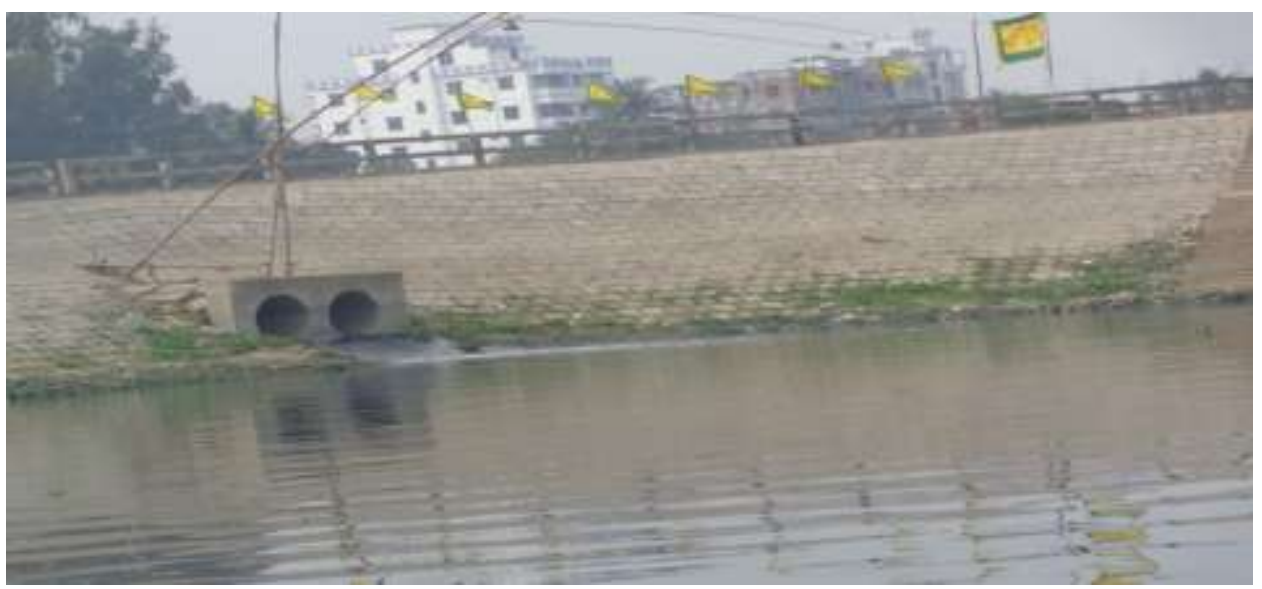

Figure 8: Storm sewers Outfalls of Turag River

\subsubsection{Open Channel Outfalls}

While not as easily recognized as pipe outfalls, a number of open channel outfalls have been identified along the banks of Turag River of the four study areas. Many household drains and industrial outfalls (Figure 9) have been seen which is mainly open. Roadside drains are the most common open channel outfalls in those areas.

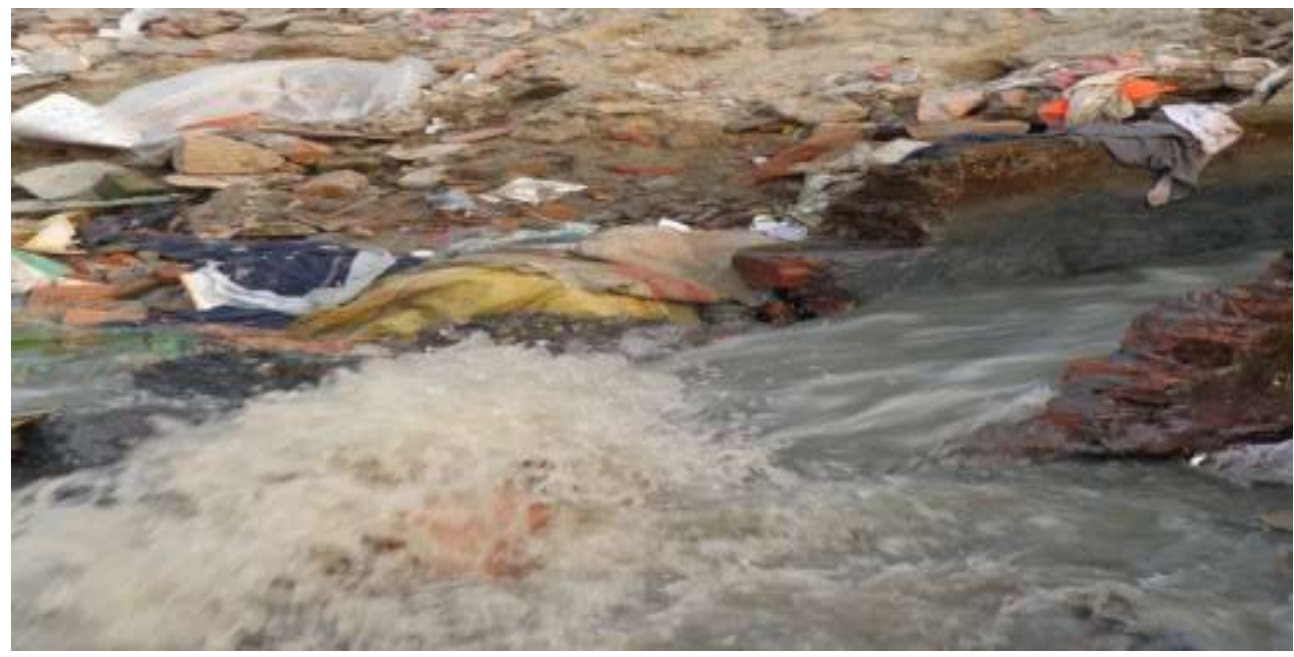

Figure 9: Open channel Outfalls of Turag River

\subsubsection{Small/ Big Private Outfalls}

In the present study, huge numbers of small / big private outfalls (Figure 10) were also observed in the study areas. These outfalls are mainly from domestic, commercial and industrial establishments.

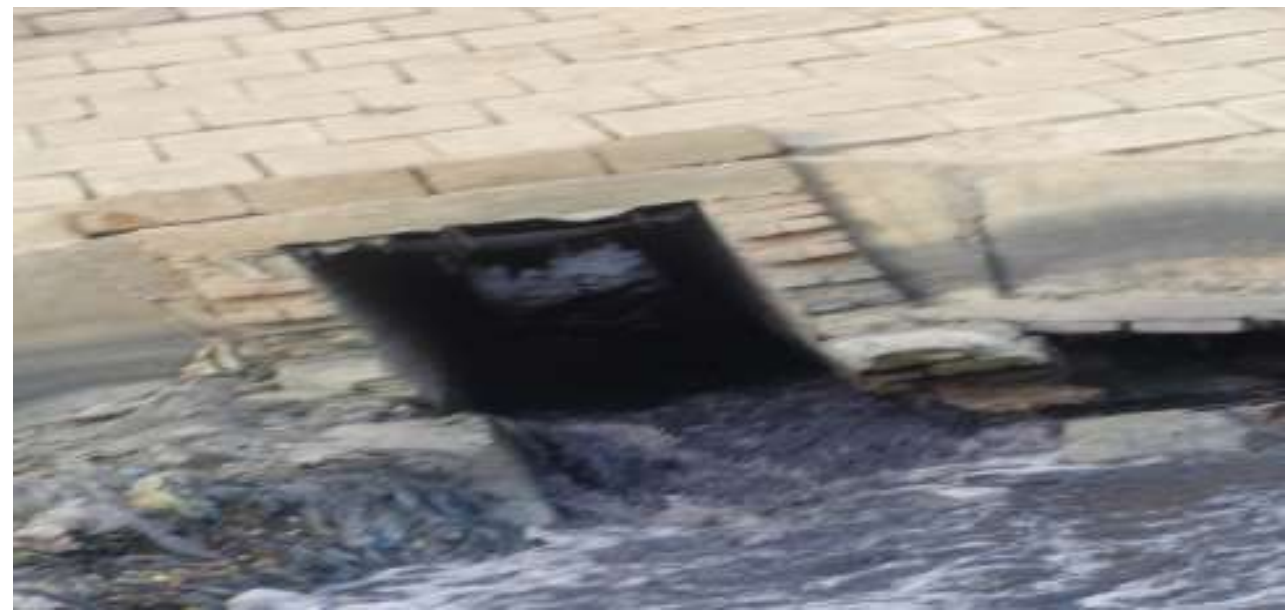

Figure 10: Small/ Big private Outfall of Turag River 


\subsection{Conclusions}

\section{Conclusions And Recommendations}

From the site visits of Turag since 2014 until 2015, it is concluded that both point sources and non point sources of pollution exist around the river. Huge piles of solid waste are also found on the embankment of Turag river. Various industrial waste water falls directly into the river through pipes, canals, open drains etc. and pollute the river water. Certain storm sewer pipes, open drains, various small and big private outfalls were also located.

Adoption of adequate measures to reduce the level of pollutants from the industrial waste water and renovation of sewage treatment plants are suggested to avoid further deterioration of the river water quality. Routine research work with wide public awareness, government participation and government regulations can save the water of Turag River and thus safe and sound water environment can be attained in future.

\subsection{Recommendations}

In an attempt to rehabilitate the Turag River, pollution of the Turag River needs to be prevented. Various efforts should be initiated in this regard which are as follows:

1. Existing laws and regulations should be implemented properly; enforcement should be adopted if required.

2. Illegal residential buildings and slums have to be removed from the bank of the river.

3. Industries, which have built up on the bank of the river illegally have to be regulated.

4. To continue the flow of the river, dredging is required.

5. To control the pollution from industrial discharge, establishment and efficient operation of Effluent Treatment Plant (ETP) is necessary.

6. A lot of untreated industrial effluents and household wastes are falling into the river which are also polluting the water. To get rid of this pollution proper treatment should be taken by the authority so that it does not pollute the river.

7. ETPs (Effluents Treatment plants) should be more effective.

8. To avoid any kinds of pollution, consciousness is the best policy, so public awareness is necessary.

9. Government agencies like (DOE, WDB, and DWASA etc.) and Non-Government agencies should be more active to reduce the pollution of the Turag.

10. From previous study report, it was seen that $90-94 \%$ pollution of Turag River is coming from industries and solid wastes. So, Keen observation is required for the industries and solid wastes generation.

\section{References}

[1]. Hossain,M.S. (2010). "Time to save the Turag from pollution”, The Daily Star (a daily newspaper), Dhaka, 8, January, 2011

[2]. Hossain,M.S. (2010). "Extreme pollution of the Turag River", The Daily Sun (a daily newspaper), Dhaka,4 December, 2010.

[3]. Tani.F (2014) "Solid Waste Management of Dhaka City: A Socio-economic analysis" ISSN: 2079-567X, Vol. 13 , No. 1 January 2014

[4]. Ahmad. M. K, Islam.S, Rahman. S, Haque.M. R, Islam. M. M (2010). "Heavy Metals in Water, Sediment and Some Fishes of Buriganga River, Bangladesh”, International Journal of Environmental Research, Vol. 4, No. 2, 2010, pp. 321-332.

[5]. Munnaf.A,Islam M.S, Tusher T.R Kabir H M, Molla A.H (2014). "Investigation of Water Quality Parameters Discharged from Textile Deying Industries”, J. Environ. Sci. \& Natural Resources, 7(1): 257 - 63, 2014 ISSN 1999-7361.

[6]. M. N. Uddin, M. S. Alam, M. N. Mobin and M. A. Miah"An Assessment of the River Water Quality Parameters: A case of Jamuna River"

[7]. Halder.J.N,Islam.M.N "Water Pollution and its Impact on the Human Health", Journal of Environment and Human ,ISSN(Print):2373-8324, ISSN(online):2373-8332.

[8]. Lindenschmidt.D.I.K.E "River water quality modelling for river basin and water resources management with a focus on the Saale River, Germany", Habilitation Thesis, Brandendurgische Technische Universitat Cottbus.

[9]. Mohamed.M "Water quality models in river management", Proceedings of the 1st Technical Meeting of Muslim Water Researchers Cooperation (MUWAREC) December 2008 (Malaysia).

[10]. Armon.R.H “Environmental Indicators” DOI 10.1007/978-94-/017-9499/2-29

[11]. "Technology-Based Emission and Effluent Standards and the Achievement of Ambient Environmental Objectives" The Yale Law Journal Vol. 91, No. 4 (Mar., 1982), pp. 792-813

[12]. The U.S. Environmental Protection Agency (EPA)" http://water.epa.gov/polwaste/nps /whatis.cfm.

[13]. Rahman, Md. Ashiqur (2011) "Towards an integrated pollution management approach for the Buriganga River in Bangladesh" Publisher: University of Sydney, Faculty of Agriculture, Food and Natural Resources.

[14]. Md. J. B. Alam, M. R. Islam, Z. Muyen, M. Mamun, S. Islam "Water quality parameters along rivers" International Journal of Environmental Science \& Technology,Vol. 01, No. 4 (2007), pp.159-167

[15]. Rahman.S "Spatial Assessment of Water Quality in Peripheral Rivers of Dhaka City for Optimal Relocation of Water Intake Point" ESRI USER's Conference 